\title{
Trends in HIV testing, prevalence among first-time testers, and incidence in most-at-risk populations in Spain: the EPI-VIH Study, 2000 to 2009
}

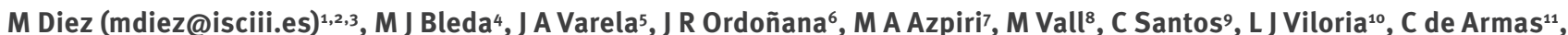 \\ J M Ureña ${ }^{12}$, J Trullén ${ }^{13}$, I Pueyo ${ }^{14}$, B Martínez ${ }^{15}$, T Puerta ${ }^{16}$, M Vera ${ }^{16}$, I Sanz ${ }^{17}, M$ L Junquera ${ }^{18}$, M C Landa ${ }^{19}$, E Martínez ${ }^{20}$, \\ M M Cámara ${ }^{21}$, J Belda ${ }^{22}$, F J Bru ${ }^{23}$, A Diaz $^{2,3}$, for the EPI-VIH Study Group ${ }^{24}$ \\ 1. Plan Nacional sobre el sida, Ministerio de Sanidad, Servicios Sociales e Igualdad, Madrid, Spain \\ 2. Área de Vigilancia Epidemiológica del VIH/sida y Comportamientos de riesgo, Centro Nacional de Epidemiología, Instituto \\ de Salud Carlos III, Madrid, Spain \\ 3. Centro de Investigación Biomédica en Red de Epidemiología y Salud Pública (CIBERESP) \\ 4. Consejo Superior de Investigaciones Científicas (CSIC), Instituto de Química Avanzada de Cataluña (IQAC), Barcelona, Spain \\ 5. Centro ETS, Gijón, Spain \\ 6. Unidad de Prevención y Educación Sanitaria sobre Sida, Murcia, Spain \\ 7. Ambulatorio Olaguibel, Comarca Araba- Osakidetza, Vitoria, Spain \\ 8. Unidad de ITS . Hospital Universitario Vall d'Hebron, Barcelona, Spain \\ 9. Centro de Información y Prevención del Sida, Valencia, Spain \\ 10. Sección de Vigilancia Epidemiológica. Dirección General de Salud Pública, Consejería de Sanidad, Santander, Spain \\ 11. Centro Dermatolológico, Tenerife, Spain \\ 12. Centro de ETS y Orientación Sexual, Granada, Spain \\ 13. Centro de Información y Prevención del Sida, Castellón, Spain \\ 14. Centro ETS, Seville, Spain \\ 15. Unidad de Promoción y Apoyo a la Salud, Málaga, Spain \\ 16. Centro Sanitario Sandoval, Servicio Madrileño de Salud, Madrid, Spain \\ 17. Plan del Sida del País Vasco, San Sebastián, Spain \\ 18. Unidad de ETS, Hospital Monte Naranco, Oviedo, Spain \\ 19. COFES Iturrama, Pamplona, Spain \\ 20. Sección de Vigilancia Epidemiológica y Control de Enfermedades Transmisibles, Dirección General de Salud Pública y \\ Consumo, Logroño, Spain \\ 21. Unidad ETS, Enfermedades Infecciosas, Hospital de Basurto, Bilbao, Spain \\ 22. Centro de Información y Prevención del Sida, Alicante, Spain \\ 23. Programa de Prevención del Sida y ETS, Madrid, Spain \\ 24. Members of the EPI-VIH Study Group are listed at the end of the article
}

Citation style for this article:

Diez M, Bleda MJ, Varela JA, Ordoñana JR, Azpiri MA, Vall M, Santos C, Viloria LJ, de Armas C, Ureña JM, Trullén J, Pueyo I, Martínez B, Puerta T, Vera M, Sanz I, Junquera ML, Landa MC, Martínez E, Cámara MM, Belda J, Bru FJ, Diaz A, for the EPI-VIH Study Group. Trends in HIV testing, prevalence among first-time testers, and incidence in most-at-risk populations in Spain: the EPI-VIH Study, 2000 to 2009. Euro Surveill. 2014;19(47):pii=20971. Available online: http://www. eurosurveillance.org/ViewArticle.aspx?Articleld=20971

Article submitted on 21 June 2013 / published on 27 November 2014

During 2000 to 2009, data on people undergoing HIV testing and on those newly diagnosed with HIV were collected in a network of 20 Spanish clinics specialising in sexually transmitted infections and/or HIV testing and counselling. The number of tests performed, overall and disaggregated by different variables, was obtained. HIV prevalence among first-time testers and HIV incidence among repeat testers were calculated. To evaluate trends, joinpoint regression models were fitted. In total, 236,939 HIV tests were performed for 165,745 individuals. Overall HIV prevalence among persons seeking HIV testing was $2.5 \%$ (95\% Cl: 2.4 to 2.6). Prevalence was highest in male sex workers who had sex with other men $(19.0 \%$ (95\% Cl: 16.7 to 21.4)) and was lowest in female sex workers (0.8\% (95\% Cl: 0.7 to 0.9)). Significant trends in prevalence were observed in men who have sex with men (MSM) (increasing) and heterosexual individuals (decreasing). The incidence analysis included 30,679 persons, 64,104 person-years (py) of follow-up and 642 seroconversions. The overall incidence rate (IR) was 1.0/100 py ( $95 \% \mathrm{Cl}: 0.9 / 100$ to $1.1 / 100)$. Incidence was significantly higher in men and transgender females than in women (1.8/100 py (95\% Cl: 1.6 to 1.9), 1.2/100 py ( $95 \% \mathrm{Cl}: 0.5$ to 2.8$)$ and $0.1 / 100$ py ( $95 \% \mathrm{Cl}: 0.09$ to 0.2) respectively) and increased with age until 35-39 years. IRs in MSM and people who inject drugs were significantly greater than in heterosexual individuals (2.5/100 py (95\% Cl: 2.3 to 2.7 ), $1.6 / 100$ py (95\% Cl: 1.1 to 2.2$)$ and $0.1 / 100$ py ( $95 \% \mathrm{Cl}: 0.09$ to 0.2$)$ respectively), and an upward trend was observed in MSM. Our results call for HIV prevention to be reinforced in MSM and transgender women in Spain.

\section{Introduction}

During the 1980 s and 90s, Spain had the highest AIDS incidence in western Europe (with a peak of 184 cases per million population in 1994), and HIV transmission was attributed in most cases to the use of contaminated material (injection equipment and substance injected) 
Flowchart of inclusion of persons undergoing HIV testing in prevalence and incidence analyses, EPI-VIH Study, Spain, 2000-09

A. Prevalence analysis

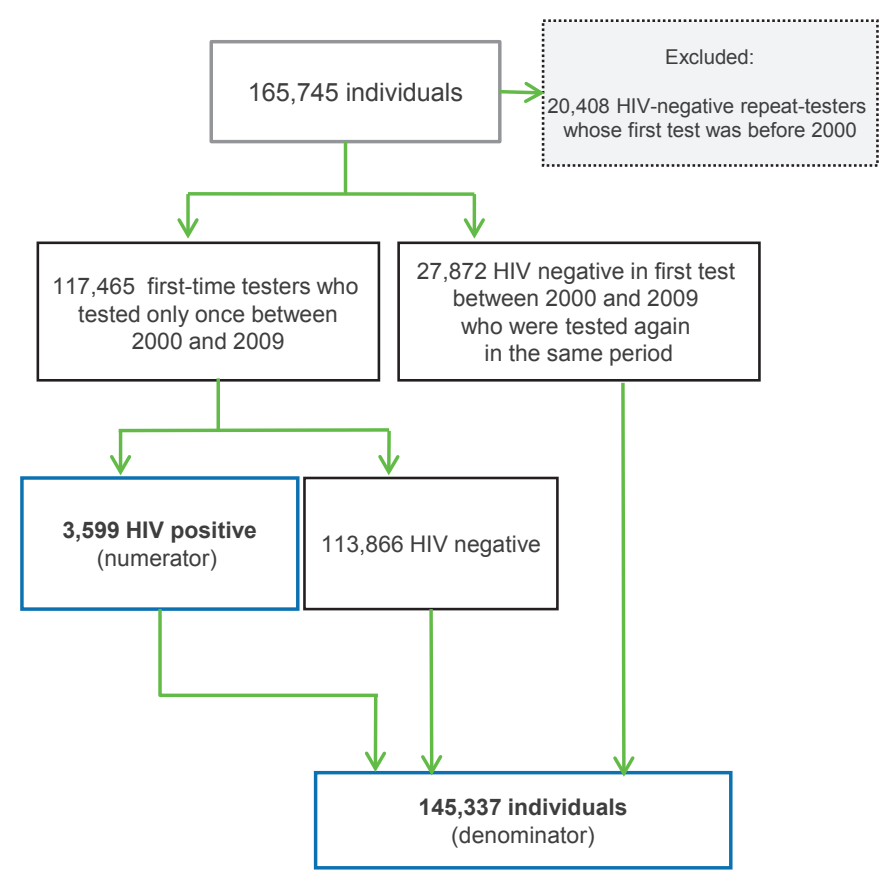

B. Incidence analysis

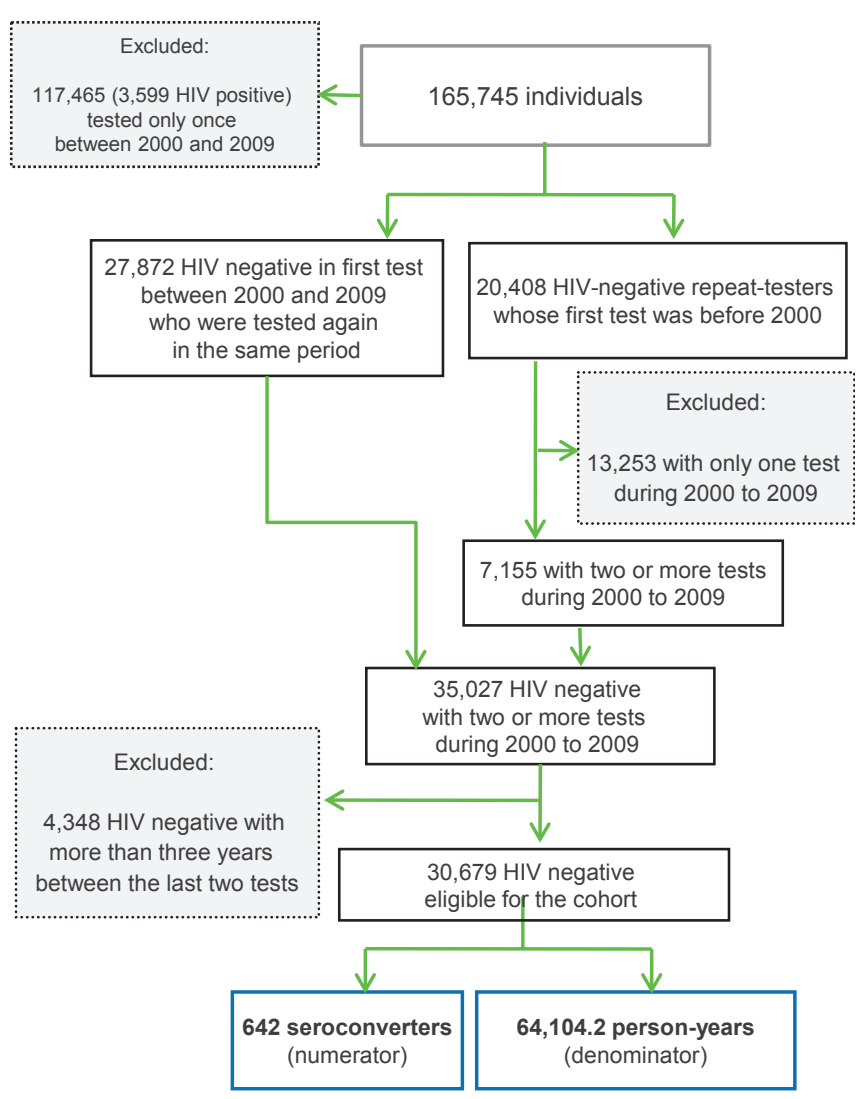

test; free-of-charge antenatal care, including HIV testing, is offered to all pregnant women. Nevertheless, actions aiming at reducing late presentation have increased, especially since 2005: these include information campaigns, opening of HIV counselling and testing (HCT) community centres, and the introduction of rapid tests in community programmes, health centres and pharmacies.

In the framework of second generation surveillance for HIV [10], the systematic collection of prevalence data in key populations is recommended for countries with concentrated epidemics, such as Spain. To this end, in 1999, the so-called EPI-VIH Study was initiated in 10 clinics (EPI-VIH Network) specialising in sexually transmitted infections (STI) or HCT. What distinguish these clinics from other public health facilities offering testing is that they are low-threshold, highly accessible centres that traditionally have attended most-at-risk populations for HIV and other STI. Analysis of retrospective and prospective data collected in the network documented a decrease in HIV prevalence from 1992 to 2002 in all most-at-risk populations, including PWID, MSM, female sex workers (FSW) and high-risk heterosexual individuals (i.e. those with a history of risk behaviours for HIV infection) $[11,12]$. 
From 2000, 10 more clinics joined the EPI-VIH Network and the EPI-VIH Study was expanded. The aim of the new project was to prospectively collect and analyse data on the following: (i) the number of HIV tests carried out in the EPI-VIH Network and characteristics of people requesting testing; (ii) HIV prevalence in mostat-risk populations attending the network clinics; and (iii) HIV incidence among all people attending the network clinics. Yearly publications describing both people tested and prevalence results [13], as well as some preliminary incidence analyses from the network [14], have provided useful insight into the HIV situation in Spain and have been used to define health policy.

The objective of this paper is to describe trends in HIV testing, HIV prevalence among first-time testers, and HIV incidence in most-at-risk populations attending the EPI-VIH Network clinics in a 10-year period, from 2000 to 2009 .

\section{Methods}

\section{The EPI-VIH Network}

From 2000 to 2009, the EPI-VIH Network comprised $20 \mathrm{STI} / \mathrm{HCT}$ clinics located in Spain's most populated cities: Madrid (two clinics), Barcelona, Seville, Bilbao, Granada, Oviedo, Gijón, San Sebastián, Vitoria, Logroño, Pamplona, Cartagena, Murcia, Málaga, Alicante, Castellón, Valencia, Santa Cruz de Tenerife and Santander. These are public, low-threshold facilities, operating free of charge, where every effort is made to maximise accessibility for most-at-risk populations. Of the 20 clinics, 13 are regular STI clinics, which offer HCT, while the remaining seven specialise in HCT. All clinics work on demand (i.e. people attending the clinic do not need to be referred by healthcare staff), no incentives are offered, and there are no differences between STI and HCT clinics regarding the provision of HIV-related services or the referral of newly diagnosed patients; nevertheless, HCT clinics were created specifically to perform HIV testing and tend to receive clients at higher risk for HIV.

Participation in the EPI-VIH Study is voluntary but, to our knowledge, all specialised STI/HCT clinics in Spain are included in the EPI-VIH Network.

\section{HIV testing practices}

All HIV tests performed in the EPI-VIH Network during the study period were analysed. The testing included pre- and post-test counselling and was performed using an enzyme-linked immunosorbent assay (ELISA) followed by a western blot to confirm positive results. For each test, people undergoing testing were classified according to whether this was the first time they had ever been tested in one of the network's clinics (first-time tester) or whether they had previously been tested in the same clinic (repeat tester). Anamnestic information about previous tests was not collected because for the incidence analysis (described below), the exact date of all tests performed had to be documented. Linkage between tests performed in different clinics was not feasible. Epidemiological information (age, sex, country of birth, date of testing, test result, status as first-time/repeat tester, and probable HIV transmission category) of the person being tested was collected through use of a questionnaire by the attending physician.

Data were collected in the context of HIV sentinel surveillance and the database was registered in the Spanish Data Protection Agency (Registry number 2080910068). No personal identifiers were collected.

\section{Study population}

All participants meeting the definition of first-time testers during the study period were included in the prevalence analysis (Figure $1 \mathrm{~A}$ ).

To estimate HIV incidence, an open cohort of people tested two or more times for HIV at one of the clinics belonging to the EPI-VIH Network between 1 January 2000 and 31 December 2009 was identified. People were eligible to enter the cohort if they met the following three criteria: (i) a documented negative result in the first HIV test performed during the study period at one of the network's clinics; (ii) at least one additional documented HIV test in the same clinic; and (iii) less than three years between their last two documented HIV tests (Figure 1B). The three-year time frame was chosen to identify true incident cases and to improve the estimates' precision.

New HIV diagnosis was defined according to the European case definition [15]. All FSW in our study had sex only with men whereas male sex workers fell into two categories: those who had sex with men (MSM sex workers) and those who had intercourse only with women. Since the latter were very few $(n=242)$ and their HIV prevalence did not differ from that of other heterosexual men, it was decided to classify them as heterosexual men for all analyses.

Statistical analyses

We calculated the number of tests performed for firsttime and repeat testers each year, stratified by type of most-at-risk populations, as well as the distribution of study participants by the variables of interest. Chi-squared tests were used to compare categorical variables.

HIV prevalence and its $95 \%$ confidence interval (CI) was calculated overall and stratified by different variables. A new HIV diagnosis for the prevalence analysis was classified as HIV prevalent when the person tested met the definition of first-time tester.

Only patients meeting the criteria for inclusion in the above-mentioned open cohort were included in the incidence analysis. Incidence rates (IR) and their 95\% Cls were calculated overall and stratified by different variables, assuming a Poisson distribution. Although 
TABLE 1

Characteristics of people undergoing HIV testing, by category of transmission, EPI-VIH Study, Spain, 2000-09 ( $\mathrm{n}=165,745$ )

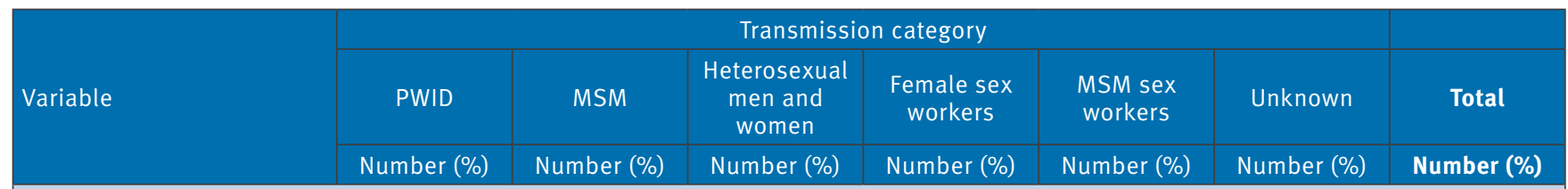

Sex

Male

Number (\%)

Number (\%)

Number (\%)

Number $(\%)$

Number $(\%)$

Number (\%)

Female

\begin{tabular}{|l|l|l|}
\hline $3,378(76.2)$ & $29,528(99.6)$ & $53,548(55.9)$ \\
\hline
\end{tabular}

Transgender women

Unknown

Age group (years)

\begin{tabular}{|l|l}
\hline$<20$ & \\
\hline $20-24$ & 6 \\
\hline
\end{tabular}

$1,051(23.7)$

NA

$954(72.5)$

$3,624(56.8)$

91,032 (54.9)

\begin{tabular}{|l|l|}
\hline $20-24$ & \\
\hline $25-29$ & \\
\hline
\end{tabular}

\begin{tabular}{c|c|c}
\hline $2(0.0)$ & $113(0.4)$ & $1(0.0)$ \\
\hline $2(0.0)$ & $3(0.0)$ & $9(0.0)$
\end{tabular}

\begin{tabular}{|l|l}
\hline $25-29$ & \\
\hline $30-34$ & \\
\hline $35-39$ & \\
\hline
\end{tabular}

$2(0.0)$

\begin{tabular}{c|}
$28,210(100.0)$ \\
$0(0.0)$
\end{tabular}

NA

$2,702(42.4)$

$74,159(44.7)$

\begin{tabular}{|c|c|c|} 
& $3(0.0)$ & $9(0.0)$ \\
\end{tabular}

$8(0.0)$

\begin{tabular}{|c|c|}
\hline $362(27.5)$ & $51(0.8)$ \\
\hline $0(0.0)$ & $3(0.0)$ \\
\hline
\end{tabular}

$529(0.3)$

\begin{tabular}{c|c}
$68(1.5)$ & \\
$478(10.8)$ &
\end{tabular}

$283(4.3)$

936 ( 21.1)

$5,969(20.1)$

4,460 (4.7)

$1,280(4.5)$

$56(4.3)$

$570(8.9)$

\section{5-39}

$1,130(25.5)$

\begin{tabular}{l|l|l}
$7,170(24.2)$ & $25,245(26.4)$ & $7,959(28.2)$
\end{tabular}

$411(31.2)$

$1,181(18.5)$

$7,717(4.7)$

$40-44$

987

45-49

$>50$

Region of birth

Spain

Western ${ }^{\text {a }}$ eastern Europe

Latin America

Sub-Saharan/North Africa

$987(22.3)$

$1,492(23.4)$

$37,550(22.7)$

Other

Unknown

Year

2000

2000

$592(13.4)$

\begin{tabular}{l|l|l}
$6,012(20.3)$ & $17,948(18.7)$ & $5,236(18.6)$
\end{tabular}

$222(16.9) \quad 1,145(17.9)$

43,193 (26.1)

\begin{tabular}{|l|l|l}
\hline $4,320(14.6)$ & $10,935(11.4)$ & $3,097(11.0)$
\end{tabular}

$123(9.3)$

$848(13.3)$

31,693 (19.1)

\begin{tabular}{l|l|l|l}
$183(4.1)$ & $1,164(3.9)$ & $4,132(4.3)$ & $590(2.1)$
\end{tabular}

$68(5.2)$

$506(7.9)$

20,310 (12.3)

$59(1.3)$

$1,313(4 \cdot 4)$

\begin{tabular}{|c|c|c|c|}
\hline $1,164(3.9)$ & $4,132(4.3)$ & $590(2.1)$ & \\
\hline $1,313(4.4)$ & $4,969(5.2)$ & $280(1.0)$ & \\
\hline & & & \\
\hline $23,612(79.7)$ & $70,351(73.5)$ & $2,147(7.6)$ &
\end{tabular}

$3,331(75.1)$

$24(1.8)$

$278(4.4)$

$11,909(7.2)$

\begin{tabular}{l|l}
$21(1.6)$ & $360(5.6)$
\end{tabular}

6,371 (3.8)

$465(10.5)$

\begin{tabular}{|l|l} 
& \\
\hline $258(19.6)$ & 4,48 \\
\hline
\end{tabular}

\begin{tabular}{|l|l} 
& \\
\hline, $486(70.3)$ & $104,185(62.9)$ \\
\hline
\end{tabular}

\begin{tabular}{|c|c|c|c|c|c|c|}
\hline & & & & & \\
\hline
\end{tabular}

HCT: HIV counselling and testing; MSM: men who have sex with men; NA: not applicable; PWID: people who inject drugs; STI: sexually transmitted infections.

a Excluding Spain.

b Northern Spain: Oviedo, Gijón, Santander, Navarre, Vitoria, Bilbao, Guipuzcoa and La Rioja. Southern Spain: Granada, Málaga and Seville. Eastern Spain: Castellón, Alicante, Valencia, Barcelona, Murcia and Cartagena. Central Spain: Madrid-Sandoval and Madrid-Ayuntamiento. Canary Islands: Tenerife. 
personal identifiers were not used in the study, linkage of different tests performed for the same person in the same clinic was possible through the use of a unique identifying number: this allowed the identification of seroconverters and the calculation of person-years ( $p y$ ) of exposure in the incidence analysis. A new HIV diagnosis for the incidence analysis was classified as HIV incident (seroconverter) if the person tested was eligible to enter the open cohort and their HIV test changed from negative to positive, i.e. they were positive in their last visit to one of the network's clinics having been HIV negative in their previous visit to the same clinic. Seroconversion was assumed to have taken place at the midpoint between the first HIV-positive visit and the last previous HIV-negative visit. To calculate py of exposure, non-seroconverters contributed the time elapsing between their first and last HIV tests during the study period, while seroconverters contributed the time elapsing between their first HIV test and the estimated date of seroconversion. For annual estimates of HIV incidence, we allocated each person's py to the years that they contributed.

To evaluate trends in the number of tests, HIV prevalence and incidence, joinpoint regression models were fitted [16]. Statistical significance was considered at a p-value 0.05 . All statistical analyses were performed using Stata statistical software (release 11.1, College Station, TX, United States, 2009.

\section{Results}

From 2000 to 2009 , a total of 236,939 HIV tests were carried out in the EPI-VIH Network for 165,745 individuals (Table 1). Of these, 117,465 were tested for the first time ever in one of the network's clinics during the study period (3,599 with a positive result) and never came back, i.e. they were tested only once; 27,872 were first-time testers at some time between 2000 and 2009: the result of the first test was negative and later they underwent testing again, thus becoming repeat testers; and 20,408 were tested for the first time before the study period with a negative result and were retested again during the study period (these persons were always considered repeat testers). People who were tested once were eligible only for the prevalence analysis; those tested before 2000 were eligible for the incidence analysis if they met the criteria to enter the open cohort. The remaining 27,872 were included in the HIV prevalence analysis the first time they were tested during the study period, and also in the HIV incidence analysis if, later on, they met the criteria to enter the open cohort (Figure $1 \mathrm{~A}$ and $1 \mathrm{~B}$ ).

In total, 145,337 individuals met the definition of firsttime tester during the study period and were eligible for the prevalence analysis, of whom 3,599 tested positive (Figure $1 \mathrm{~A}$ ).

There were initially 48,280 HIV-negative repeat-testers potentially eligible to enter the open cohort: the 27,872 and 20,408 mentioned above. Of the latter, 13,253 had only one HIV test during the study period and therefore were excluded from the open cohort. Of the remaining 35,027 HIV-negative individuals with two or more HIV tests during the study period, 4,348 were excluded because more than three years had passed between their last two tests, leaving 30,679 HIV-negative subjects eligible for the cohort. Over the study period, they totalled $64,104.2$ py of follow-up and 642 seroconverters were identified among them (Figure 1B).

\section{HIV tests}

The 236,939 tests took place in the following years: $17,402(7.3 \%)$ in $2000,19,436(8.2 \%)$ in $2001,22,244$ (9.4\%) in 2002, 22,389 (9.4\%) in 2003, 24,395 (10.3\%) in $2004,24,639(10.4 \%)$ in $2005,25,723(10.9 \%)$ in $2006,26,502(11.2 \%)$ in $2007,27,797(11.7 \%)$ in 2008 and $26,412(11.1 \%)$ in 2009.

Of the total tests, $145,337(61.3 \%)$ were carried out in first-time testers and 91,596 (38.7\%) in repeat testers; in six instances, no information was available. Over the study period, the annual number of tests increased significantly ( $p<0.05$ ) among both first-time and repeat testers: in first-time testers, the increase was $44.7 \%$, from 11,084 tests performed in 2000 to 16,035 in 2009; in repeat-testers, the increase was $64.2 \%$, from 6,318 in 2000 to 10,377 in 2009 .

First-time testers differed from repeat testers most notably by transmission category. The majority, 87,120 (59.9\%), of first-time testers were heterosexual individuals (men and women), 24,600 (16.9\%) were FSW, 24,099 (16.6\%) MSM, 3,182 (2.2\%) PWID, 1,222 (0.8\%) MSM sex workers and 5,114 (3.5\%) unknown. Among repeat testers, 28,792 (31.4\%) were FSW, 26,817 (29.3\%) MSM, 27,129 (29.6\%) heterosexual individuals, 3,369 (3.7\%) PWID, 1,258 (1.4\%) MSM sex workers and 4,231 (4.6\%) unknown.

The number of tests significantly increased from 2000 to 2009 in first-time and repeat testers in all most-atrisk populations except PWID and FSW. In first-time testers, the number of tests increased in MSM from 1,483 to 2,943 ( $p<0.05$ ), in heterosexual individuals from 5,848 to 10,723 ( $p<0.05$ ) and in MSM sex workers from 63 to 113 ( $p<0.05$ ). In PWID, it decreased from 630 to 130 ( $p<0.05$ ) and from 2,432 to 1,592 ( $p<0.05$ ) in FSW. In repeat testers, the number of tests increased in MSM from 1,760 to 3,555 ( $p<0.05$ ), in heterosexual individuals from 1,927 to 3,425 ( $p<0.05$ ) and in MSM sex workers from 71 to 151 ( $p<0.05)$. The number decreased in PWID from 561 to 225 (p<0.05). Among FSW, the number of tests increased from 1,811 to 3,394 ( $p<0.05$ ) from 2000 to 2005 and decreased afterwards, to 2,319 in $2009(p<0.05)$.

In about four of 10 tests, the person tested was born outside Spain $(52,358 / 145,337(36.0 \%)$ of tests in first-time testers vs $36,380 / 91,596(39.7 \%)$ in repeat testers). In first-time testers, the proportion of foreigners increased during 2000 to 2002, from 2,993/8,594 
TABLE 2

HIV prevalence in people undergoing HIV testing, by different variables, EPI-VIH Study, Spain, 2000-09 (n=145,337)

\begin{tabular}{|c|c|c|c|c|c|c|c|c|c|c|c|}
\hline \multirow[b]{2}{*}{ Variables } & \multicolumn{10}{|c|}{ Prevalence (\%) by year of diagnosis } & \multirow{2}{*}{$\begin{array}{c}\text { Total } \\
\mathrm{n}=145,337 \\
\%(95 \% \mathrm{Cl})\end{array}$} \\
\hline & $\begin{array}{c}2000 \\
n= \\
11,084\end{array}$ & $\begin{array}{c}2001 \\
n= \\
12,466\end{array}$ & $\begin{array}{c}2002 \\
n= \\
13,559\end{array}$ & $\begin{array}{c}2003 \\
n= \\
13,647\end{array}$ & $\begin{array}{c}2004 \\
n= \\
14,937\end{array}$ & $\begin{array}{c}2005 \\
n= \\
14,895\end{array}$ & $\begin{array}{c}2006 \\
n= \\
15,366\end{array}$ & $\begin{array}{c}2007 \\
n= \\
16,160\end{array}$ & $\begin{array}{c}2008 \\
n= \\
17,188\end{array}$ & $\begin{array}{c}2009 \\
n= \\
16,035\end{array}$ & \\
\hline \multicolumn{12}{|l|}{ Sex } \\
\hline Male & 4.5 & 3.4 & 3.4 & 3.4 & 3.2 & 4.0 & 3.3 & 3.1 & 3.8 & 3.8 & $3.6(3.4$ to 3.7$)$ \\
\hline Female & 1.5 & 1.5 & 0.9 & 1.2 & 1.2 & 0.9 & 0.8 & 0.8 & 0.9 & 0.6 & $1.0(1.0$ to 1.1$)$ \\
\hline Transgender women & 0.0 & 18.8 & 33.3 & 20.0 & 20.5 & 29.7 & 25.0 & 26.6 & 26.5 & 22.0 & $24.5(20.4$ to 29.0$)$ \\
\hline \multicolumn{12}{|l|}{ Age group (years) } \\
\hline$<20$ & 0.8 & 0.8 & 0.7 & 1.0 & 1.5 & 0.5 & 0.6 & 1.6 & 1.6 & 0.8 & $1.0(0.8$ to 1.3$)$ \\
\hline $20-24$ & 1.7 & 1.5 & 1.2 & 1.4 & 1.5 & 1.9 & 1.2 & 1.4 & 2.1 & 1.9 & $1.6(1.5$ to 1.7$)$ \\
\hline $25-29$ & 2.6 & 1.5 & 2.0 & 2.4 & 1.8 & 1.9 & 2.4 & 2.5 & 2.7 & 2.7 & $2.2(2.1$ to 2.4$)$ \\
\hline $30-34$ & $4 \cdot 3$ & 3.4 & 3.4 & 3.0 & 2.6 & 3.9 & 2.2 & 2.4 & 2.8 & 2.9 & $3.0(2.8$ to 3.2$)$ \\
\hline $35-39$ & 5.9 & 4.7 & 3.4 & 4.8 & 4.0 & 3.7 & 3.8 & 2.7 & 2.6 & 3.0 & $3.7(3.5$ to 4.0$)$ \\
\hline $40-44$ & 3.6 & 4.7 & 3.6 & 2.7 & 4.1 & 4.1 & 3.8 & 2.9 & 3.6 & 3.5 & $3.7(3.3$ to 4.0$)$ \\
\hline $45-49$ & 2.9 & 2.2 & 1.6 & 2.6 & 2.8 & 3.0 & 3.1 & 2.5 & 4.6 & 4.4 & $3.1(2.7$ to 3.6$)$ \\
\hline$>50$ & 4.2 & 4.1 & 1.6 & 1.0 & 2.1 & 2.6 & 2.0 & 2.4 & 3.4 & 2.2 & $2.5(2.1$ to 2.9$)$ \\
\hline \multicolumn{12}{|l|}{ Region of birth } \\
\hline Spain & 3.0 & 2.6 & 2.0 & 2.2 & 2.1 & 2.3 & 1.8 & 1.9 & 2.3 & 2.4 & $2.2(2.1$ to 2.3$)$ \\
\hline Western Europe ${ }^{a}$ & 3.4 & 3.4 & 1.7 & 3.0 & 2.5 & 3.2 & 2.1 & 1.3 & 2.1 & 1.9 & 2.3 (2.0 to 2.8$)$ \\
\hline Eastern Europe & 1.1 & 1.5 & 3.0 & 1.6 & 1.1 & 1.7 & 2.0 & 1.5 & 2.5 & 1.6 & $1.8(1.4$ to 2.1$)$ \\
\hline Latin America & 1.5 & 2.0 & 2.1 & 2.2 & 2.5 & 3.5 & 3.4 & 3.2 & 3.9 & 3.3 & 2.8 (2.6 to 3.0$)$ \\
\hline Sub-Saharan Africa & 5.4 & 5.4 & 5.8 & 6.8 & 6.9 & 6.9 & 3.0 & 4.9 & 3.8 & 4.7 & $5.3(4.7$ to 6.0$)$ \\
\hline North Africa & 0.9 & 2.3 & 3.6 & 3.8 & 2.6 & 3.1 & 3.0 & 1.8 & 0.9 & 2.7 & $2.5(1.9$ to 3.3$)$ \\
\hline \multicolumn{12}{|l|}{ Type of clinic } \\
\hline $\mathrm{HCT}$ & 5.4 & 3.7 & 3.0 & 2.9 & 3.0 & 2.7 & 2.8 & 3.4 & 2.8 & 3.2 & $3.2(3.0$ to 3.5$)$ \\
\hline STI & 2.5 & 2.2 & 2.1 & 2.3 & 2.2 & 2.6 & 2.1 & 2.0 & 2.7 & 2.5 & $2.3(2.2$ to 2.4$)$ \\
\hline Total & 3.0 & 2.5 & 2.2 & 2.4 & 2.3 & 2.7 & 2.2 & 2.2 & 2.7 & 2.6 & $2.5(2.4$ to 2.6$)$ \\
\hline
\end{tabular}

$\mathrm{CI}$ : confidence interval; HCT: HIV counselling and testing; STI: sexually transmitted infections.

a Excluding Spain.

(34.8\%) to $5,612 / 13,558$ (41.4\%), decreasing thereafter to $5,420 / 16,035(33.8 \%)$ in 2009 (statistically significant trend with a turning point in 2002, p<0.05). The proportion of foreigners among people testing several times followed a similar pattern, but the trend was not statistically significant. Latin America was the most common region of birth among foreigners $(60,526$ $(25.5 \%)$ of the total number of tests), followed by eastern Europe $(9,430(4 \%))$.

\section{HIV prevalence}

In total, 145,337 persons, of whom 3,599 were HIVpositive, were tested for the first time ever in one of the network's clinics during the study period (Figure 1A). Of the 3,599 found to be positive, 1,484 ( $41.2 \%)$ were born outside Spain, with the proportion ranging from 15.6\% (84/540) among PWID to $90.7 \%$ (195/215) among MSM sex workers.

The overall HIV prevalence during the study period in these first-time testers was $2.5 \%(95 \% \mathrm{Cl}: 2.4-2.6)$ and was higher in HCT than in STI clinics $(3.2 \%(95 \% \mathrm{Cl}$ : 3.0 to 3.5 ) vs $2.3 \%$ ( $95 \% \mathrm{Cl}: 2.2$ to 2.4$)$ ). HIV prevalence was highest in transgender women $(24.5 \%(95 \% \mathrm{Cl}$ : 20.4 to 29.0)), and increased with age until it reached a peak of $3.7 \%(95 \% \mathrm{Cl}: 3.5$ to 4.0$)$ in the age group 35-39 years (Table 2). These differences in prevalence were statistically significant.

Very high HIV prevalence estimates throughout the study period were found among MSM sex workers (19.0\%; range: $10.5-24.5)$ and PWID (17.0\%; range: 13.3-21.2), although in both groups, yearly estimates were rather unstable because the number of MSM sex workers was small and the number of PWID decreased over the study period. Among MSM, HIV prevalence during the study was $7.6 \%$, ranging from $6.4 \%$ in 2001 to $9.4 \%$ in 2009 . Prevalence was much lower in heterosexual individuals (0.9\%; range: $0.7-1.1$ ) and FSW (0.8\%; range: $0.5-1.2$ ). There were no differences by sex in HIV prevalence among heterosexual individuals, therefore combined estimates are presented. Joinpoint 
models fit to evaluate trends in HIV prevalence by transmission category showed a decreasing trend in heterosexual individuals and an increasing trend in MSM (Figure 2).

Foreign-born participants had a higher HIV prevalence during the study period than did those who were Spanish born (2.9\% (95\% Cl: 2.7 to 3.0 ) vs $2.2 \%$ (95\% $\mathrm{Cl}: 2.1$ to 2.3), pro.05) and the same was true for each region of birth except eastern Europe. An increasing trend in HIV prevalence was observed among Latin American-born participants ( $p<0.05$ ) (Table 2).

\section{HIV incidence}

In all, 30,679 individuals entered the open cohort, totalling $64,104.2$ py of follow-up and 642 seroconverters. The majority of eligible persons 17,288 (56.3\%), tested only twice during the study period, 6,068 (19.8\%) tested three times and 7,323 (23.9\%) tested more than three times; the corresponding figures among seroconverters were 289 (45.0\%), 136 (21.2\%) and 217 (33.8\%). The median time between tests was 9.3 months (interquartile range: 5.9-15.7) for the overall cohort and 10.6 months for seroconverters (interquartile range: 6.3-17.6).

The overall HIV IR for the study period was 1.0 seroconversions/100 py (95\% Cl: $0.9 / 100$ to $1.1 / 100)$, with no statistically significant differences by type of clinic. The IR was highest in the country's biggest cities, Madrid, Barcelona, Valencia and Seville (1.5/100 py (95\% Cl: 1.4 to 1.7$), 1.1 / 100$ py (95\% Cl: 0.8 to 1.5 ), 1.2/10opy (95\% Cl: 0.9 to 1.4 ) and $1.0 / 100$ py (95\% Cl: 0.8 to 1.3 ) respectively), although Bilbao, which has about the same population as Valencia or Seville, had a much lower IR (0.4/100 py ( $95 \% \mathrm{Cl}$ : 0.3 to 0.7$)$ ). In general, centres located in northern Spain had lower seroconversion rates than those located in the eastern and southern parts of the country. Men and transgender females had higher IR than women (1.8/100 py (95\% Cl: 1.6 to 1.9 ), $1.2 / 100$ py ( $95 \% \mathrm{Cl}: 0.5$ to 2.8 ) and $0.1 / 100$ py ( $95 \% \mathrm{Cl}: 0.09$ to 0.2$)$ respectively). With respect to age, the peak IR was found in people younger than 20 years, but the sample size was small, with a wide $95 \%$ $\mathrm{Cl}$. The next highest IR was in the 35-39 year age group (1.2/100 py; $95 \% \mathrm{Cl}: 1.0$ to 1.5$)$. Spanish-born participants as well as those born elsewhere in Europe had higher seroconversion rates than people born outside Europe (Table 3).

Results by transmission category showed that the highest IR was among MSM sex workers (3.0/100 py), although the $95 \% \mathrm{Cl}$ was quite wide (2.2 to 4.1), followed by MSM who were not sex workers and PWID (2.5/100 py (95\% Cl: 2.3 to 2.7 ) and $1.6 / 100$ py (95\% $\mathrm{Cl}: 1.1$ to 2.2$)$ respectively). Since there were no differences in HIV incidence between male and female heterosexual individuals, combined estimates are presented (Table 3).
Joinpoint models fit to evaluate trends in incidence showed a statistically significant increase in overall HIV incidence over the study period, but stratification by transmission category showed that the increasing trend was present only among MSM (Figure 3).

\section{Discussion}

During the study period, the number of HIV tests increased in MSM, heterosexuals and MSM sex workers but not among PWID and FSW. HIV prevalence decreased in heterosexual individuals and increased in MSM, remaining stable in the other transmission categories. HIV incidence was highest among MSM sex workers and showed an increasing trend in MSM. The study provides seroconversion estimates among migrants after their arrival in Spain.

Early HIV diagnosis and treatment is a policy priority in Spain [9] and the total number of HIV tests performed increased from 24.8 per 1,000 inhabitants in 2002 to 38.2 per 1,000 in 2009 [17]. Our results suggest that the increase in testing is not uniform across most-atrisk populations and that testing might actually be decreasing in some groups. The reduced number of tests among PWID seems logical because the PWID population is rapidly decreasing [6], but the decrease observed among FSW warrants further investigation. There are some data on the size of the FSW population in Spain [18] but none on its trend, although a decrease in the number of FSW that might explain the decrease in testing in this group seems unlikely. A change in the testing facilities preferred by FSW seems equally unlikely, because the clinics in the network are free of charge, highly accessible and have a long tradition of caring for this population. A more likely explanation is worsening access to these clinics in the network due to the increased proportion of foreign FSW - from $46 \%$ in 1998 [19] to 93\% in 2009 (our study) - and the shift in the working environment from outdoors to indoors (i.e. apartments or clubs), a tendency noted throughout Europe, which makes sex workers less accessible to intervention measures [20]. The lack of HIV prevalence data among FSW working only indoors in Spain warrants further investigation.

Decreasing trends in HIV prevalence among all most-atrisk populations were reported from 1992 to 2001 in the 10 centres that initially comprised the network $[11,12]$. Data from the expanded network show that from 2000 to 2009, HIV prevalence remained stable among PWID and male and female sex workers, and increased in MSM, whereas it continued to decrease only in heterosexual individuals. This last group has increased the most in size; thus, declining HIV prevalence could also be a result of testing more people at lower risk.

HIV prevalence in transgender women was higher than that found previously in other Spanish studies [21,22]. In comparison with other countries, our figure (24.5\%) is higher than the $\mathbf{2 1 . 7 \%}$ reported in the United States and the same as the $24.5 \%$ found in Italy according to 

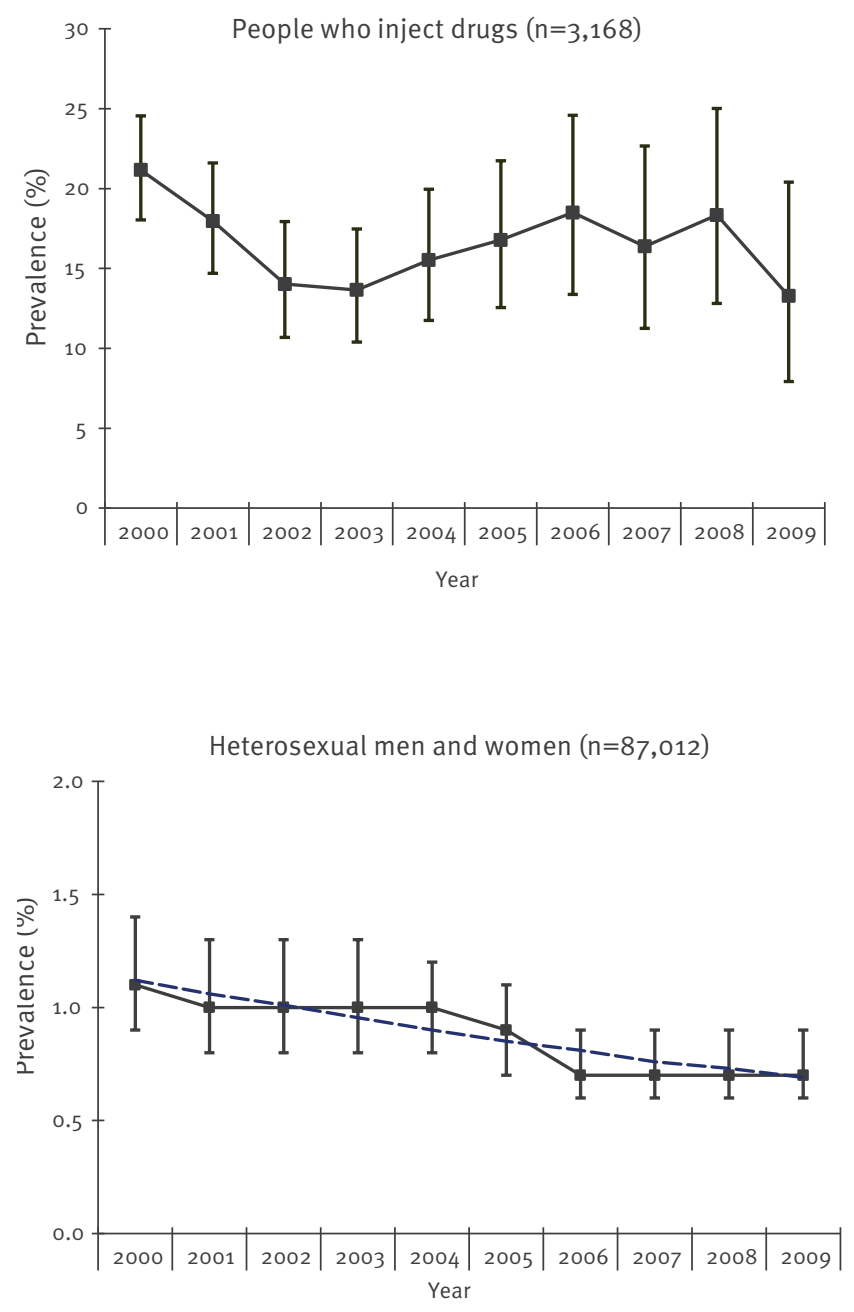

- - Joinpoint model annual percentage change: -5.3 (95\% Cl: -6.8 to -3.8$)$, pro.05
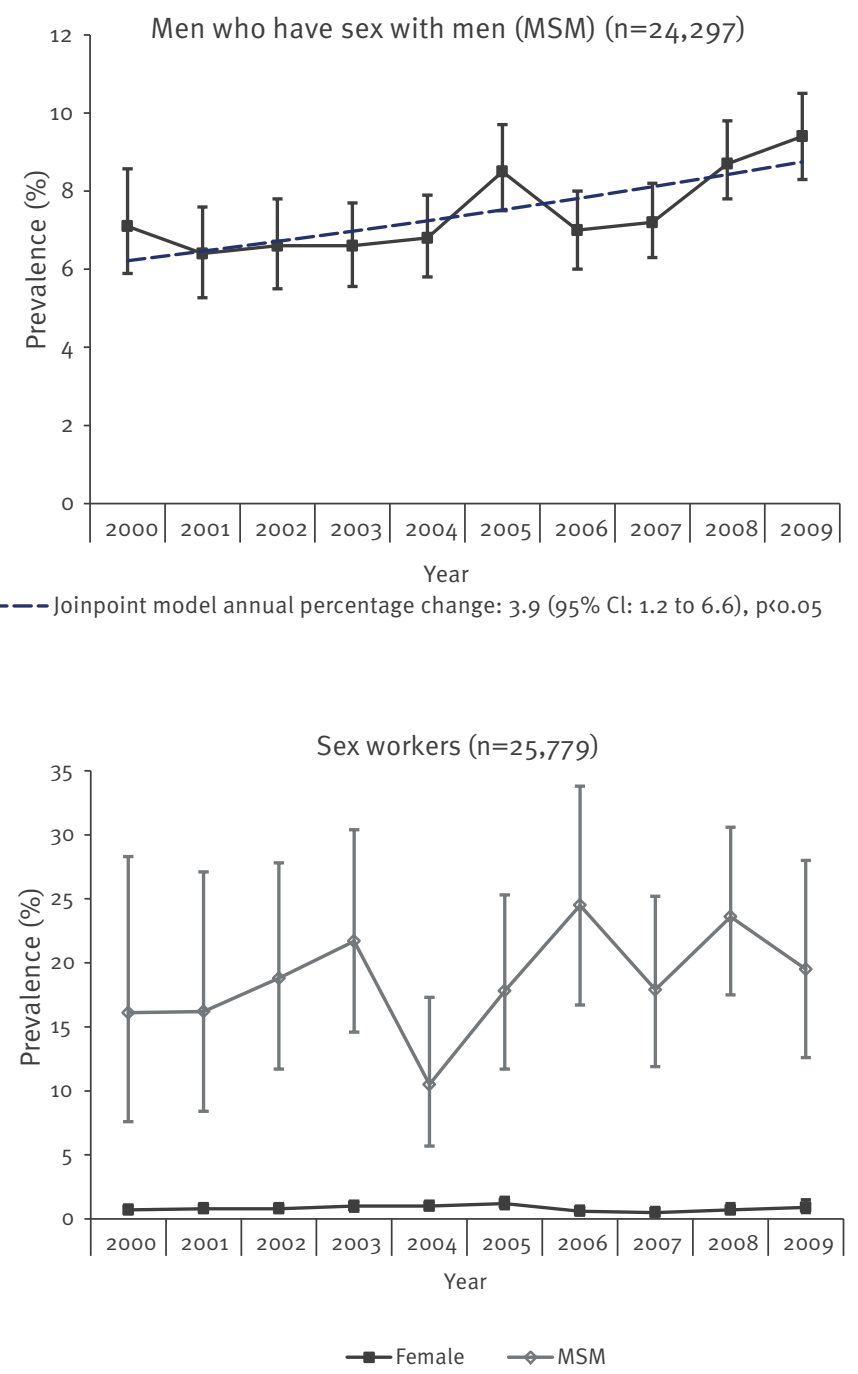

[12] has been reversed, which is not surprising given our findings that HIV incidence is also on the rise in MSM. The overall IR for MSM in our study (2.5/100 py) was lower than that found among American or Italian MSM in the 1990 s $(2.8 / 100$ py and $4.6 / 100$ py respectively) $[29,30]$ or that estimated in Bangkok during 2003 to 2007 (from 4.1 to $7.7 \%$ ) [27], but higher than figures reported in London, England, in 1997 to 1998 (1.8/100 py) or Catalonia, Spain, during 1995 to 2001 $(1.92 / 100$ py) $[31,32]$.

HIV prevalence among PWID in this study was a third to a half of what it was in the 1980s and 9os in Spain $[11,33]$, although the overall prevalence was very high ( $17 \%)$, only lower than that found among MSM sex workers. During the study period, these figures remained stable. Compared with other studies, the HIV prevalence was lower than the $26.9 \%$ self-reported HIV infection among PWID entering drug treatment in 2009 in Spain [34] and similar to the $17.2 \%$ found in 
TABLE 3

HIV incidence rate in people undergoing HIV testing, by different variables, EPI-VIH Study, Spain, 2000-09 (n=30,679)

\begin{tabular}{|c|c|c|c|c|}
\hline Variable & $\begin{array}{c}\text { Number of persons } \\
\text { tested }\end{array}$ & $\begin{array}{c}\text { Number of } \\
\text { seroconversions }\end{array}$ & Person-years & Incidence rate ${ }^{a}(95 \% \mathrm{Cl})$ \\
\hline \multicolumn{5}{|l|}{ Sex } \\
\hline Male & 15,672 & 601 & $34,086.2$ & $1.8(1.6$ to 1.9$)$ \\
\hline Female & 14,840 & 36 & $29,588.1$ & $0.1(0.09$ to 0.2$)$ \\
\hline Transgender women & 167 & 5 & 429.8 & $1.2(0.5$ to 2.8$)$ \\
\hline \multicolumn{5}{|l|}{ Age group (years) } \\
\hline$<20$ & 1,193 & 14 & $1,051.2$ & $1.3(0.8$ to 2.3$)$ \\
\hline $20-24$ & 6,899 & 88 & $9,595.1$ & $0.9(0.7$ to 1.1$)$ \\
\hline $25-29$ & 8,071 & 163 & $15,886.3$ & $1.0(0.9$ to 1.2$)$ \\
\hline $30-34$ & 6,304 & 163 & $14,737.5$ & $1.1(1.0$ to 1.3$)$ \\
\hline $35-39$ & 4,065 & 132 & $10,826.6$ & $1.2(1.0$ to 1.5$)$ \\
\hline $40-44$ & 2,126 & 50 & $6,178.0$ & 0.8 (o.6 to 1.1 ) \\
\hline $45-49$ & 1,015 & 19 & $2,974.2$ & 0.6 (0.4 to 1.0$)$ \\
\hline$>50$ & 1,006 & 13 & $2,855.2$ & $0.5(0.3$ to 0.8$)$ \\
\hline \multicolumn{5}{|l|}{ Region of birth } \\
\hline Spain & 15,970 & 423 & $33,340.2$ & $1.3(1.2$ to 1.4$)$ \\
\hline Western ${ }^{b} /$ Eastern Europe & 1,912 & 29 & $3,224.5$ & 0.9 (0.6 to 1.3$)$ \\
\hline Latin America & 9,796 & 121 & $19,999.2$ & $0.6(0.5$ to 0.7$)$ \\
\hline Sub-Saharan/ North Africa & 1,132 & 8 & $1,901.6$ & $0.4(0.2$ to 0.8$)$ \\
\hline Other & 167 & 6 & 250,4 & $2.4(1.1$ to 5.3$)$ \\
\hline \multicolumn{5}{|l|}{ HIV transmission category } \\
\hline PWID or ex-PWID & 884 & 32 & $2,016.1$ & $1.6(1.1$ to 2.2$)$ \\
\hline MSM & 8,492 & 529 & $21,181.0$ & $2.5(2.3$ to 2.7$)$ \\
\hline Heterosexual men and women & 10,500 & 23 & $17,914.2$ & 0.1 (0.09 to 0.2$)$ \\
\hline Female sex worker & 9,808 & 16 & $21,027.9$ & $0.1(0.05$ to 0.1$)$ \\
\hline MSM sex worker & 549 & 39 & $1,311.0$ & $3.0(2.2$ to 4.1$)$ \\
\hline \multicolumn{5}{|l|}{ Year } \\
\hline 2000 & 4,294 & 20 & $2,161.9$ & $0.9(0.6$ to 1.4$)$ \\
\hline 2001 & 3,337 & 28 & $4,825.2$ & $0.6(0.4$ to 0.8$)$ \\
\hline 2002 & 3,566 & 37 & $6,378.7$ & $0.6(0.4$ to 0.8$)$ \\
\hline 2003 & 3,330 & 55 & $7,445.2$ & 0.7 (0.6 to 1.0$)$ \\
\hline 2004 & 3,407 & 77 & $8,203.6$ & 0.9 (0.8 to 1.2$)$ \\
\hline 2005 & 3,133 & 70 & $8,510.6$ & 0.8 (o.7 to 1.0$)$ \\
\hline 2006 & 3,181 & 87 & $8,483.1$ & $1.0(0.8$ to 1.3$)$ \\
\hline 2007 & 3,134 & 105 & $8,152.6$ & $1.3(1.1$ to 1.6$)$ \\
\hline 2008 & 2,410 & 110 & $6,848.3$ & $1.6(1.3$ to 1.9$)$ \\
\hline 2009 & 887 & 53 & $3,095.0$ & 1.7 (1.3 to 2.2$)$ \\
\hline \multicolumn{5}{|l|}{ HIV/STI clinic locationc } \\
\hline Northern Spain & 6,341 & 36 & $11,819.5$ & $0.3(0.2$ to 0.4$)$ \\
\hline Southern Spain & 3,828 & 83 & $8,426.8$ & $1.0(0.8$ to 1.2$)$ \\
\hline Eastern Spain & 9,809 & 195 & $20,482.2$ & 0.9 (o.8 to 1.1$)$ \\
\hline Central Spain & 9,321 & 301 & $20,787.5$ & $1.4(1.3$ to 1.6$)$ \\
\hline Canary Islands & 1,380 & 27 & $2,588.2$ & $1.0(0.7$ to 1.5$)$ \\
\hline \multicolumn{5}{|l|}{ Type of clinic } \\
\hline $\mathrm{HCT}$ & 5,056 & 106 & $10,764.2$ & 0.9 (0.8 to 1.2) \\
\hline STI & 25,623 & 536 & $53,340.0$ & $1.0(0.9$ to 1.1$)$ \\
\hline Total & 30,679 & 642 & $64,104.2$ & $1.0(0.9$ to 1.1$)$ \\
\hline
\end{tabular}

HCT: HIV counselling and testing; MSM: men who have sex with men; PWID: people who inject drugs; STI: sexually transmitted infections.

${ }^{a}$ Number of seroconversions per 100 person-years.

b Excluding Spain.

'Northern Spain: Oviedo, Gijón, Santander, Navarre, Vitoria, Bilbao, Guipuzcoa and La Rioja.

Southern Spain: Granada, Málaga and Seville.

Eastern Spain: Castellón, Alicante, Valencia, Barcelona, Murcia and Cartagena.

Central Spain: Madrid-Sandoval and Madrid-Ayuntamiento.

Canary Islands: Tenerife. 
HIV incidence rate ${ }^{a}$ by year of diagnosis and transmission category, EPI-VIH Study, Spain, 2000-09 (n=30,679)
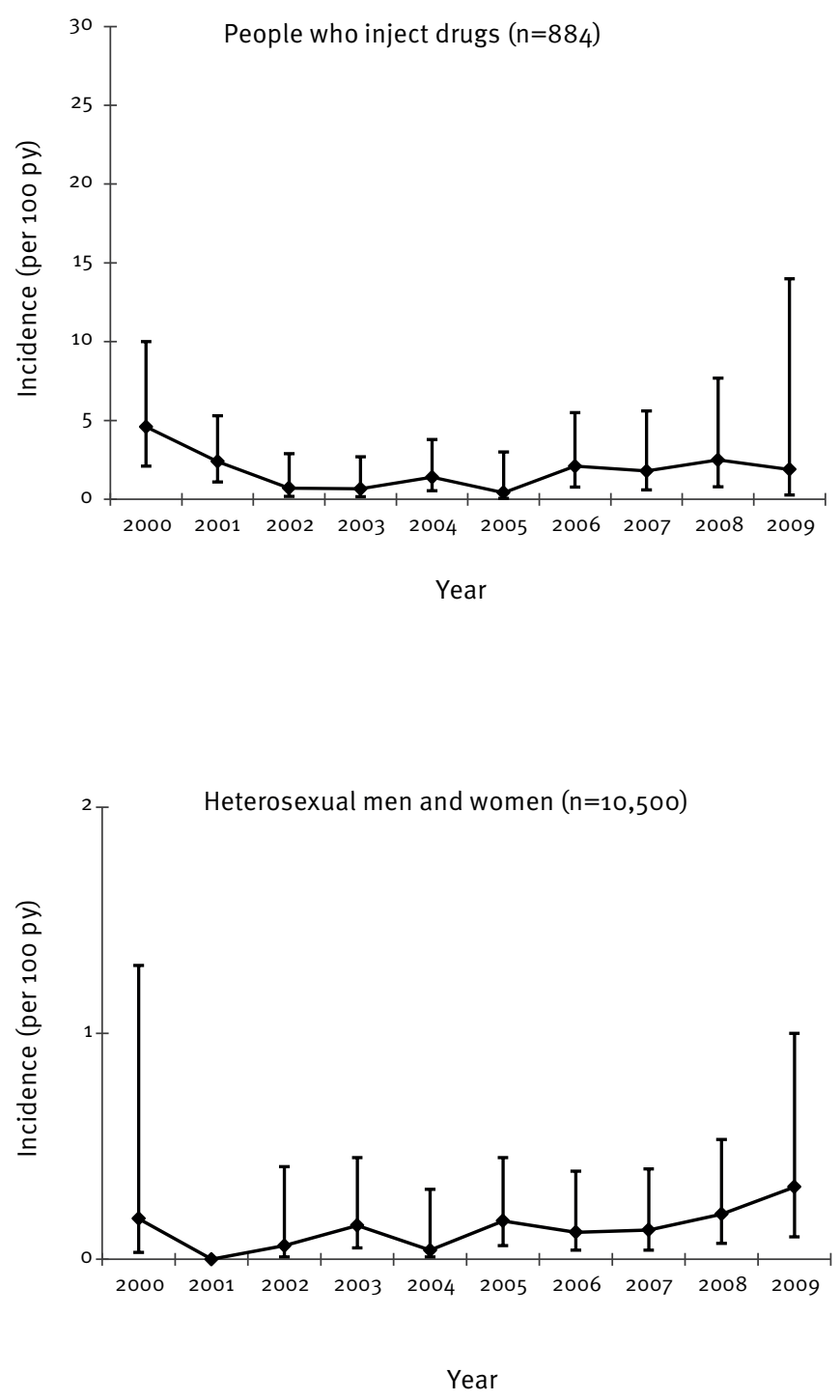

Bars represent $95 \%$ confidence intervals (CIs).

${ }^{a}$ Number of seroconversions per 100 person-years (p-y).

Portugal in the same setting in 2009, but this was to be expected since PWID attending clinics in the EPI-VIH network are likely to have better social conditions than other PWID in Spain; in any case, these prevalence figures indicate that Spanish PWID are still among the most HIV-infected PWID in the European Union [35]. Surveillance data show that new HIV diagnoses in PWID in Spain have decreased sharply since 2004 [36], as a result of the decrease in the size of the PWID population and decreased HIV transmission after implementation of harm reduction programmes $[4,6]$; however, our findings show that seroconversion among current injectors, though much less frequent than in the past $[37,38]$, is still very common.

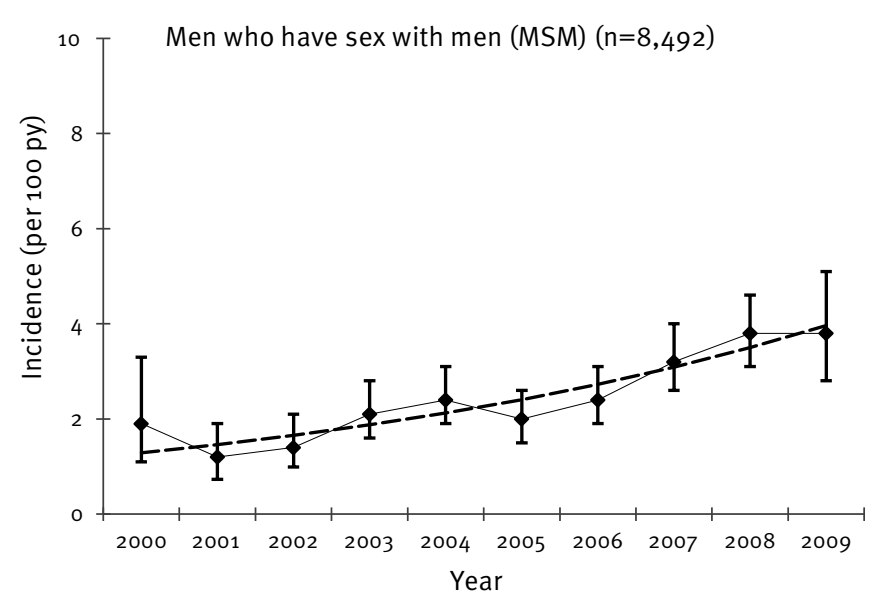

- - Joinpoint model annual percentage change: 13.3 ( $95 \% \mathrm{Cl}: 8.3$ to 18.5 ), pro.05

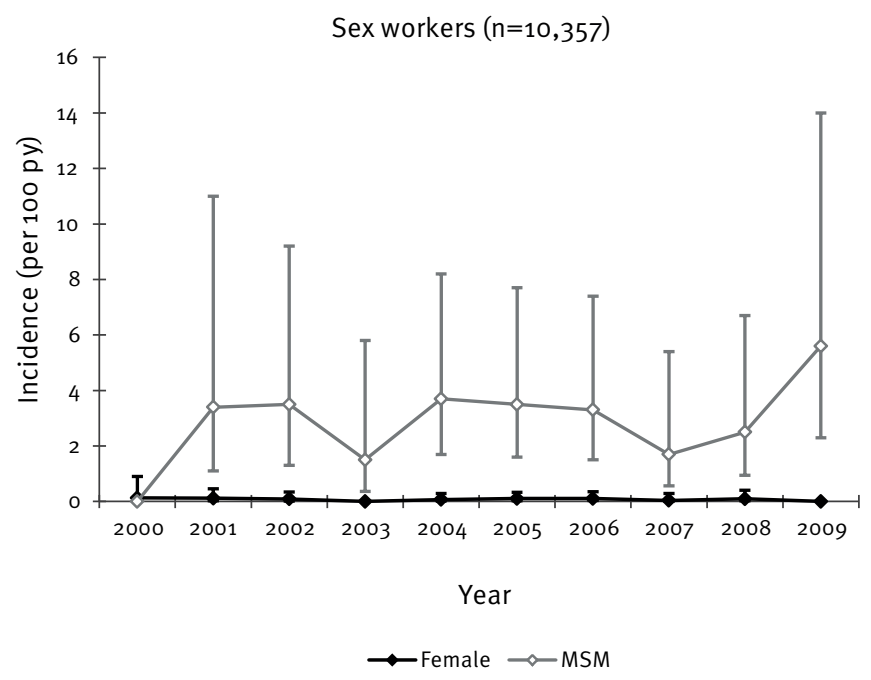

Latin-American migrants have always been present in Spain, but their numbers increased greatly since the mid-1990s, and since 2000 people from other areas have also been attracted to the country [8]. Migration into Spain is therefore a relatively recent phenomenon, so the generally higher HIV prevalence among foreignborn people in our study probably reflects the HIV prevalence in their country of origin, as well as differences in the distribution of HIV transmission categories between those who were Spanish-born and the other groups. However, the diagnostic delay among those newly diagnosed with HIV in Spain is greater among people who are foreign-born [39], in spite of them 
being entitled to HIV testing and care free of charge; thus, it is possible that they are experiencing difficulties in accessing HIV testing and care due to discrimination or other barriers.

Our HIV incidence estimates in MSM (2.5/100 py) are fairly similar to those found in MSM in California, United States, from 1997 to 2006 (2.0/100 py in 1997, increased to $2.4 / 100$ py in 2003 and then decreased to $1.9 / 100$ py in 2006) [40], but whereas researchers in California report a decreasing trend there since 2003 , the opposite is occurring in our setting. The rising trend in incidence among MSM in our study is consistent with findings from surveillance data in Spain showing an increase in the number of new HIV diagnoses in this group, but not in heterosexual individuals or PWID since 2004 [36]. While part of this increase could be the result of more frequent testing, other sub-populations in our study have a similar trend in testing but not in new HIV diagnoses. Furthermore, other studies in Spain have documented an over-representation of MSM among syphilis and gonorrhoea cases in 2006 [41] as well as outbreaks of lymphogranuloma venereum and hepatitis A in MSM since 2007 [42-45]. Behavioural monitoring in this group has found an increase in risk behaviours [46].

This study has some limitations. People attending the clinics in the EPI-VIH Network are by no means representative of the general Spanish population and the reasons for seeking care in the network are not independent of HIV infection: thus the results cannot be extrapolated to other settings. However, while the estimates presented probably reflect only the experience of the population at greater risk of HIV infection in each transmission category, the clinics have been operating on the same basis for many years, so if selection biases are present, they are unlikely to affect the results on trends. A change in the populations attending the clinics could influence trends, thus multivariate analyses need to be performed to have a better insight into the results. The questionnaires were administered by many individuals, making it difficult to control reproducibility. Testing patterns in the different most-at-risk populations might have evolved over the years in a different way. Finally, for some groups, e.g. transgender individuals, the numbers were very small.

The information obtained with this study shows the changing face of HIV epidemiology in Spain, is of great public health relevance and very useful for adjusting HIV policy to the real needs. In contrast with the $1980 \mathrm{~s}$ and 90s, when most HIV infections occurred among PWID, MSM have emerged as the population at greatest risk for HIV in Spain and should be given priority in preventive efforts. Nevertheless, although injection of drugs is becoming rare, PWID should not be forgotten since HIV prevalence and incidence in this group remains very high and shows no signs of decreasing.
HIV infection remains a huge problem in transgender women and MSM sex workers that warrants further research in preventive interventions in these groups. With regard to FSW, efforts should be made to guarantee access to HIV testing and prevention, in particular for those working in places not easy to reach. Investigation of the situation of those who are hard to reach is also a priority. In addition, this study illustrates the increasing impact of migrants on the HIV epidemic in Spain; interventions tailored to their needs should therefore be urgently promoted.

\section{Acknowledgements}

This work has been supported with grants No. 36303/02, 36537/05 and 36794/08 from FIPSE (Fundación para la Investigación y la Prevención del Sida en España). The authors wish to thank Kathy Fitch for the English review.

\section{Conflict of interest}

None declared.

\section{Authors' contributions}

MD was the main study researcher. She supervised field work and data collection, wrote the statistical analysis plan and the first version of the manuscript. MJB performed data collection and management, quality control and statistical analysis, and reviewed all the manuscript drafts. AD prepared the figures and most of the tables and made important contributions to successive versions of the manuscript. JAV, JRO, MAA, MV, CS, LJV, CA, JMU, JT, IP, BM, TP, MV, IS, MLJ, $M C L, E M, M M C, J B, F J B$ and EPI-VIH Study Group: were the clinicians responsible for patient recruitment and follow-up in the participating centres. They all participated in development of the study protocol, collection of epidemiological and clinical data, and critical review of all versions of the manuscript

\section{Members of the EPI-VIH Study Group}

M Diez, A Diaz, F Sánchez, S Galindo, MJ Bleda (Centro Nacional de Epidemiología, Madrid); JM Ureña, E Castro, V Benavides, M Gómez (Centro de ETS y Orientación Sexual, Granada); B Martínez, MA García, L Godoy (Unidad de Promoción y Apoyo a la Salud, Málaga); I Pueyo, E Ruiz, C Redondo, C Martínez, D Sánchez (Centro de ETS, Sevilla); JA Varela, C López, L Otero (Unidad de ETS, Gijón); ML Junquera, M Cuesta, F Vázquez, F Carreño (Unidad de ETS. Hospital Monte Naranco, Oviedo); M Vall, MJ Barberá, A Álvarez, M Arando, E Arellano, P Armengol, M Gosch, MP Saladié, A Vives (Unidad ITS, Hospital Universitario Vall d'Hebron , Barcelona); FJ Bru, C Colomo, A Comunión, R Martín, S Marinero (Programa de Prevención del Sida, Madrid); J Belda, E Fernández, T Zafra, S Colomina, E Galán (Centro de Información y Prevención del Sida, Alicante); J Alastrué, C Santos, T Tasa, A Juan, E Fernandez, E Domenech (Centro de Información y Prevención del Sida, Valencia); J Trullen, A Fenosa, C Altava, A Polo (Centro de Información y Prevención del Sida, Castellón); J Balaguer, Al Villafane (Unidad de ETS-Sida, Centro Salud Área II, Cartagena); MM Cámara, J López de Munain, MN Aparicio, MA Aizpuru (Unidad ETS, Enfermedades Infeccionas, H. Basurto, Bilbao); I Sanz, X Camino (Plan del Sida del País Vasco. San Sebastián); C de Armas, E García-Ramos, J Rodríguez-Franco, MA Gutiérrez, L Capote, D Nuñez (Centro Dermatológico de Tenerife); 
LJ Viloria, C Fernández-Oruña (Sección de Vigilancia Epidemiológica, Servicio de Salud Pública, Consejería de Sanidad. Santander), MC Fernández, M de Vierna, A Estébanez, D Álvarez, F del Rio (COF La Cagiga, Santander); J del Romero, C Rodríguez, T Puerta, P Clavo, S García, S del Corral, B Menéndez, MA Neila, N Jerez, M Raposo, J Ballesteros, M Vera (Centro Sanitario Sandoval, Servicio Madrileño de Salud, Madrid); JR Ordoñana, J Ballester (Unidad de Prevención y Educación Sanitaria sobre SIDA, Murcia); MC Landa, H Yagüe, P Sánchez, A Gaztambide, Huarte, E Sesma, J Benito (COFES Iturrama, Pamplona); MA Azpiri (Consulta VIH. Ambulatorio Olaguibel. Comarca ArabaOsakidetza,Vitoria); E Martínez, ME Lezaun, L Metola, C Quiñones, E Ramalle, M Perucha, V Ibarra, JA Otero (Sección de Vigilancia Epidemiológica y Control de Enfermedades Transmisibles, DG de Salud Pública y Consumo, Logroño).

\section{References}

1. European Centre for the Epidemiological Monitoring of AIDS (EuroHIV). HIV/AIDS surveillance in Europe. End-year report 1999. Saint-Maurice: EuroHIV; 2000. No. 62. Available from: http://ecdc.europa.eu/en/activities/surveillance/hiv/ Documents/report_eurohiv_endyear_99.pdf

2. Cambios recientes en la epidemia de SIDA en Espa-a. Registro Nacional de SIDA. Situación a 31 de marzo de 1998. [Recent changes in the AIDS epidemic in Spain. National AIDS case registry. Situation at 31st March 1998]. Boletin Epidemiológico Semanal. 1997;5(30):281-4. Spanish. Available from: http:// gesdoc.isciii.es/gesdoccontroller?action=download\& id $=25 / 04 / 2013-8$ doodd 9 ccd

3. Castilla J, de la Fuente L. [Trends in the number of human immunodeficiency virus infected persons and AIDS cases in Spain: 1980-1998]. Evolución del número de personas infectadas por el virus de la inmunodeficiencia humana y de los casos de SIDA en Espa-a: 1980-1998. Med Clin (Barc). 2000;115(3):85-9. Spanish. http://dx.doi.org/10.1016/ So025-7753(00)71473-4

4. Torrens M, Fonseca F, Castillo C, Domingo-Salvany A. Methadone maintenance treatment in Spain: the success of a harm reduction approach. Bull World Health Organ. 2013;91(2):136-41. http://dx.doi.org/10.2471/BLT.12.111054

5. Mathers BM, Degenhardt L, Phillips B, Wiessing L, Hickman M, Strathdee SA, et al. Global epidemiology of injecting drug use and HIV among people who inject drugs: a systematic review. Lancet. 2008;372(9651):1733-45. http://dx.doi.org/10.1016/ S0140-6736(08)61311-2

6. Barrio Anta G, Oliva J, Bravo MJ, De Mateo S, Domingo-Salvany A; Itinere Working Group. Estimating the prevalence of drug injection using a multiplier method based on a register of new HIV diagnoses. Eur | Public Health. 2011;21(5):646-8. http:// dx.doi.org/10.1093/eurpub/ckq076

7. European Centre for Disease Prevention and Control (ECDC)/ WHO Regional Office for Europe. HIV/AIDS surveillance in Europe 2010. Stockholm: ECDC: 2011. Available from: http:// ecdc.europa.eu/en/publications/Publications/111129_SUR_ Annual_HIV_Report.pdf

8. National Statistical Institute (INE). Municipal Register. Statistical use at 1st January 2012. Madrid: INE. [Accessed 10 Sep 2013]. Available from: http://www.ine.es/jaxi/menu.do;jse ssionid $=2$ A94Aoo8F2B8C35BE8FA9731D2CAC 273.jaxio1?type $=$ pcaxis \& path $=\% 2 \mathrm{Ft} 20 \% 2 \mathrm{Fe} 245 \&$ file $=$ inebase $\& \mathrm{~L}=1$

9. Ministerio de Sanidad y Consumo. Plan Multisectorial frente a la infección por VIH y el sida. Espa-a 2008-2012. [Multisectorial Plan against HIV infection and AIDS. Spain 2008-2012]. Madrid Ministerio de Sanidad y Consumo; 2008. Spanish. Available from: http://www.msssi.gob.es/ciudadanos/enfLesiones/ enfTransmisibles/sida/publicaciones/planesMultisec.htm

10. UNAIDS/WHO Working Group on Global HIV/AIDS and STI Surveillance. Guidelines for second generation HIV surveillance. Geneva: World Health Organization (WHO) and Joint United Nations Programme on HIV/AIDS (UNAIDS); 2000. WHO/CDS/CSR/EDC/2000.5. UNAIDS/00.03E. Available from: http://www.who.int/hiv/pub/surveillance/en/cds_ edc 2000 5.pdf

11. del Romero J, Rodríguez C, García S, Ballesteros J, Clavo $P$, Neila MA, del Corral S, et al. [HIV prevalence among homosexual and bisexual men in Spain, 1992-2000]. Med Clin (Barc). 2002;119(11):413-5. Spanish. http://dx.doi.org/10.1016/ So025-7753(02) $73436-2$
12. Barrasa A, Castilla J, del Romero J, Pueyo I, de Armas C, Varela JA, et al. Sentinel surveillance of HIV infection in HIV test clinics, Spain 1992-2002. Euro Surveill. 2004;9(5):pii=466.

13. Grupo EPI-VIH. Estudio prospectivo de prevalencia de VIH en personas atendidas en una red de centros de diagnóstico de VIH/ITS, 2000-2010. [Prospective study of HIV prevalence in clients of a network of HCT/STI clinics, 2000-2010]. Madrid: Centro Nacional de Epidemiología; 2012. Spanish. Available from: http://www.msssi.gob.es/ciudadanos/enfLesiones/ enfTransmisibles/sida/vigilancia/InformeEPI VIH2000 2010. pdf

14. Diez M, Sanchez F, Landa MC, Martínez E, Cámara MM, EPIVIH Study Group. HIV incidence in most at risk populations in Spain, 2000-2007. Presentation at HIV in European Region Unity and Diversity. Tallinn, Estonia, 25-27 May 2011.

15. European Commission. Commission decision of 28 April 2008 amending Decision 2002/253/EC laying down case definitions for reporting communicable diseases to the Community network under Decision No 2119/98/EC of the European Parliament and of the Council. Official Journal of the European Union. Luxembourg: Publications Office of the European Union. 18.6.2008:L 159. Available from: http://eur-lex.europa.eu/ legal-content/EN/TXT/PDF/?uri=CELEX:32008D0426\&qid =1416 917059240\&from $=\mathrm{EN}$

16. Kim HJ, Fay MP, Feuer EJ, Midthune DN. Permutation tests for joinpoint regression with applications to cancer rates. Stat Med. 2000;19(3):335-51. http://dx.doi.org/10.1002/ (SICI)1097-0258(20000215)19:3〈335::AID-SIM336〉3.0.CO;2-Z

17. Secretaría del Plan Nacional sobre el Sida. Informe del Cuestionario de Actividades de Prevención del VIH en las Comunidades Autónomas. A-0 2009. [Report on HIV prevention activities in the Autonomous Regions in Spain. Year 2009]. Madrid: Secretaría del Plan Nacional sobre el Sida, Dirección General de Salud Pública y Sanidad Exterior, Ministerio de Sanidad, Política Social e Igualdad; 2010. Spanish. Available from: http://www.msssi.gob.es/ciudadanos/enfLesiones/ enfTransmisibles/sida/docs/ICAP2009.pdf

18. Centro de Investigaciones Sociológicas (CIS). Encuesta Nacional de Salud Sexual 2009. [National Survey on Sexual Health 2009]. Madrid: CIS. [Accessed 1 Jun 2011]. Spanish. Available from: http://www.cis.es/cis/opencm/ES/1 encuestas/estudios/ver.jsp?estudio $=9702 \&$ cuestionario $=1129$ 6\&muestra $=17045$

19. [Seroprevalence of HIV infection among sexually transmitted disease clinic attenders. Study Group of the Seroprevalence of Anonymous HIV Unrelated to Patients Consulting a Sexually Transmitted Disease Clinic]. Med Clin (Barc). 2000;114(6):211-3.

20. TAMPEP (European Network for HIV/STI Prevention and Health Promotion among Migrant Sex Workers). European overview of HIV and sex work. Amsterdam: TAMPEP; 2007. Available from: http://tampep.eu/documents/European\%200verview\%20 of $\% 20$ HIV\%20and\%20Sex\%2oWork.pdf

21. Belza MJ. Risk of HIV infection among male sex workers in Spain. Sex Transm Infect. 2005;81(1):85-8. http://dx.doi. org/10.1136/sti.2003.008649

22. Gutiérrez M, Tajada $P$, Alvarez A, De Julián R, Baquero $M$, Soriano V, et al. Prevalence of HIV-1 non-B subtypes, syphilis, HTLV, and hepatitis $B$ and C viruses among immigrant sex workers in Madrid, Spain. J Med Virol. 2004;74(4):521-7. http:// dx.doi.org/10.1002/jmv.20208

23. Baral SD, Poteat T, Strömdahl S, Wirtz AL, Guadamuz TE, Beyrer C. Worldwide burden of HIV in transgender women: a systematic review and meta-analysis. Lancet Infect Dis. 2013;13(3):214-22. http://dx.doi.org/10.1016/ S1473-3099(12)70315-8

24. Zaro Rosado I, Peláez Murciego M, Chacón García A. Trabajadores masculinos del sexo: aproximación a la prostitución masculina en Madrid. [Male sex workers: an approach to sex work among men in Madrid]. Madrid: Ministerio de Sanidad y Consumo, Comunidad de Madrid, Fundación Triángulo; 2006. Spanish. Available from: http:// www.fundaciontriangulo.org/documentacion/documentos/ trabajadoresmasculinos.pdf

25. Meulbroek M, Ditzel E, Saz J, Taboada H, Pérez F, Pérez A, et al. BCN Checkpoint, a community-based centre for men who have sex with men in Barcelona, Catalonia, Spain, shows high efficiency in HIV detection and linkage to care. HIV Med. 2013;Suppl 3;25-8. 10.1111/hiv.12054. http://dx.doi. org/10.1111/hiv.12054

26. Folch C, Casabona J, Mu-oz R, Zaragoza K. [Trends in the prevalence of HIV infection and risk behaviors in homo-and bisexual men]. Gac Sanit. 2005;19(4):294-301. http://dx.doi. org/10.1157/13078039

27. van Griensven F, Varangrat A, Wimonsate W, Tanpradech S, Kladsawad K, Chemnasiri T, et al. Trends in HIV prevalence, estimated HIV incidence, and risk behavior among men who have sex with men in Bangkok, Thailand, 2003-2007. J 
Acquir Immune Defic Syndr. 2010;53(2):234-9. http://dx.doi. org/10.1097/QAl.ob013e3181c2fc86

28. Centers for Disease Control and Prevention (CDC). Prevalence and awareness of HIV infection among men who have sex with men --- 21 cities, United States, 2008. MMWR Morb Mortal Wkly Rep. 2010;59(37):1201-7.

29. McFarland W, Kellogg TA, Dilley J, Katz MH. Estimation of human immunodeficiency virus (HIV) seroincidence among repeat anonymous testers in San Francisco. Am J Epidemiol. 1997;146(8):662-4. http://dx.doi.org/10.1093/oxfordjournals. aje.a009332

30. Suligoi B, Giuliani M, Galai N, Balducci M. HIV incidence among repeat HIV testers with sexually transmitted diseases in Italy. STD Surveillance Working Group. AIDS. 1999;13(7):845-50. http://dx.doi.org/10.1097/00002030-199905070-00015

31. Elford J, Leaity S, Lampe F, Wells H, Evans A, Miller R, et al. Incidence of HIV infection among gay men in a London HIV testing clinic, 1997-1998. AIDS. 2001;15(5):650-3. http://dx.doi. org/10.1097/00002030-200103300-00018

32. Nascimento CM, Casado MJ, Casabona J, Ros R, Sierra $\mathrm{E}$, Zaragoza K, et al. Estimation of HIV incidence among repeat anonymous testers in Catalonia, Spain. AIDS Res Hum Retroviruses. 2004;20(11):1145-7. http://dx.doi. org/10.1089/0889222042544956

33. Hernández-Aguado I, Avi-o MJ, Pérez-Hoyos S, González-Aracil J, Ruiz-Pérez I, Torrella A, et al. Human immunodeficiency virus (HIV) infection in parenteral drug users: evolution of the epidemic over 10 years. Valencian Epidemiology and Prevention of HIV Disease Study Group. Int J Epidemiol. 1999;28(2):335-40. http://dx.doi.org/10.1093/ije/28.2.335

34. Observatorio Espa-ol de la Droga y las Toxicomanías. Situación y tendencias de los problemas de drogas en Espa-a. A-0 2011. [Situation and trends of drug problems in Spain. Year 2011]. Madrid: Delegación del Gobierno para el Plan Nacional sobre Drogas; 2011. Spanish. Available from: http://www.pnsd.msc. es/Categoria2/observa/pdf/oed2011.pdf

35. European Monitoring Centre for Drugs and Drug Addiction (EMCDDA). Table INF-108. Prevalence of HIV infection among injecting drug users (\%), 1991 to 2009 . EU countries, Croatia, Turkey and Norway. Statistical Bulletin 2011. Drug-related infectious diseases (DRID). Lisbon: EMCDDA. Available from: http://www.emcdda.europa.eu/stats11/inftab108

36. Diez M, Oliva J, Sánchez F, Vives N, Cevallos C, Izquierdo A, et al. [Incidence of new HIV diagnoses in Spain, 2004-2009]. Gac Sanit. 2012;26(2):107-15. Spanish. http://dx.doi.org/10.1016/j. gaceta.2011.07.023

37. Avi-o Rico MJ, Hernández Aguado I, Perez Hoyos S, García de la Hera M, Ruiz I, Bolumar Montrull F. [The incidence of human immunodeficiency virus type-1 (HIV-1) infection in parenteral drug users]. Med Clin (Barc). 1994;102(10):369-73. Spanish.

38. Marco A, Gallego C, Caylà JA, Guerrero RA, Puértolas A, Da Silva A. Estudio de la seroincidencia del VIH en población recluida en una prisión espa-ola a partir de determinaciones analíticas repetidas. [Study of seroincidence of HIV amongst inmates in a Spanish prison using repeated analytical determinations]. Rev Esp Sanid Penit. 2001;3(2):60-4. Spanish.

39. Diez M, Oliva J, Diaz A, Andonegui J, Alvarez M, Castilla J, et al. Retraso diagnóstico en nuevos diagnósticos de VIH en 8 CCAA. [Delayed diagnosis in new HIV diagnoses in 8 Autonomous Regions]. Gac Sanit. 2007; 21(Espec Congr):70. Abstract. Spanish. Available from: http://gacetasanitaria.org/ es/pdf/13111675/S300/

40. Xia Q, Nonoyama A, Molitor F, Webb D, Osmond D. Recent decline in the incidence of human immunodeficiency virus infection among California men who have sex with men. Am J Epidemiol. 2011;174(2):203-10. http://dx.doi.org/10.1093/aje/ kwro54

41. Diez M, Diaz A, Vall M, Pueyo I, Lopez de Munain, Ure-a JM, et al. HIV infection and outcome of treatment among patients with syphilis and gonorrhoea. Presentation at Conference on Sexually Transmitted Infections and HIV/AIDS, International Union Against Sexually Transmitted Infections Europe (IUSTI), Milan, Italy, 4-6 September 2008.

42. Vargas-Leguas H, Garcia de Olalla P, Arando M, Armengol $P$, Barbera $M$, Vall $M$, et al. Lymphogranuloma venereum: a hidden emerging problem, Barcelona, 2011. Euro Surveill. 2012;17 (2): pii=20057.

43. Savage EJ, van de Laar MJ, Gallay A, van der Sande M, Hamouda O, Sasse A, et al. Lymphogranuloma venereum in Europe, 2003-2008. Euro Surveill. 2009;14(48):pii=19428.

44. Tortajada C, de Olalla PG, Pinto RM, Bosch A, Caylà J. Outbreak of hepatitis $A$ among men who have sex with men in Barcelona, Spain, September 2008-March 2009. Euro Surveill. 2009;14(15):pii=19175.

45. Puerta López T, Rodríguez Domínguez MJ, Menéndez Prieto B, Rodríguez Martín C, Ballesteros Martín J. Clavo escribano
$P$, et al. Brote de linfogranuloma venéreo en la Comunidad de Madrid. [Outbreak of lymphogranuloma venereum in the Madrid Community]. Presentation at II Congreso Nacional de Grupo de Estudio de Sida (GESIDA), Madrid, 27-30 November 2010. Spanish

46. Folch C, Casabona J, Mu-oz R, González V, Zaragoza K. IIncrease in the prevalence of HIV and in associated risk behaviors in men who have sex with men: 12 years of behavioral surveillance surveys in Catalonia (Spain)]. Gac Sanit. 2010;24(1):40-6. Spanish. http://dx.doi.org/10.1016/j. gaceta.2009.06.010 